\title{
The State of the Art in Music Education Research in Brazil
}

\author{
Cristina Rolim Wolffenbüttel ${ }^{1}$, Romeu Riffatti ${ }^{1}$, Guilherme da Silva Ramos ${ }^{1}$ \\ ${ }^{1}$ Music Department, State University of Rio Grande do Sul, Montenegro, Brazil \\ Correspondence: Cristina Rolim Wolffenbüttel, Music Department, State University of Rio Grande do Sul, Montenegro, \\ Brazil.
}

Received: November 7, 2019

Accepted: November 21, 2019

Available online: November 27, 2019

doi:10.11114/ijsss.v8i1.4626

URL: https://doi.org/10.11114/ijsss.v8i1.4626

\begin{abstract}
This article presents the results of research that aimed to map the scientific production in Music Education in the last twelve years. The reason for this dating lies on the fact that in 2006 a process was started for the insertion of music in schools, through Bill No. 330, culminating in Law No. 11.769/2008, which provides for the obligation of music teaching in basic education. Subsequently, Resolution No. 2 consolidated this obligation. From then on, there was an increase in scientific production in Music Education in Brazil. Thus, this research came from the questions: What subjects have been investigated in Music Education in Brazil in the last twelve years? What methodologies were used in these surveys? What are the theoretical references that underlie these investigations? What is the impact of these research studies on the Brazilian scientific scenario? Based on these questions, this research aimed to investigate the state of the art of musical education in Brazil in the last twelve years. The methodological design of the research was developed from data collection via the Internet, and data analysis was based on the use of content analysis. Among the results, it was observed that the themes of research in Music Education have been diversified, presenting a strong relationship with the political and educational issues involved and which underlie the pedagogical-musical work.
\end{abstract}

Keywords: music education, state of the art, production in Music Education, mapping, Brazil

\section{Introduction}

This article originates from (a) research that investigated the state of the art of scientific production in Music Education in Brazil in the last twelve years.

Ferreira (2002) explained that in recent years there has been a significant production of the state of the art research type. The author uses the terms state of art and state of knowledge as similar. According to Ferreira (2002),

"Defined as bibliographic, they seem to bring together the challenge of mapping and discussing a certain academic production in different fields of knowledge, trying to answer which aspects and dimensions have been highlighted and privileged in different times and places, in what forms and in what conditions they have been produced in certain master's dissertations, doctoral theses, journal publications and conference proceedings. They are also recognized for having an inventive and descriptive methodology of academic and scientific production on the subject that seeks to investigate, in the light of categories and facets that are characterized as such in each work and in all of them, under which the phenomenon becomes analyzed" (Ferreira, 2002: p. 258).

For the present investigation the methodologies used in the research in Music Education were identified, the theoretical references that support them, the researched subjects in the field and the impacts of this production in the Brazilian scientific scenario. The choice to investigate the last twelve years of the scientific production in Music Education in Brazil is explained by the fact that in 2006 (Bill No. 330) was presented in the Federal Senate, authored by Senator Roseana Sarney. This menu proposed the amendment of Law No. 9.394 from 1996, known as the Law of Guidelines and Bases of Education (LBDEN No. 9.394/96), to provide for the compulsory teaching of music in Basic Education. After all the procedures, this law was approved, resulting in the signing by President Luis Inácio Lula da Silva, on August 18, 2008, through Law No. 11.769. This law amended article 26 of "LDBEN No. 9.394/96", making it compulsory, but not exclusive, the teaching of music in Basic Education. During and after the period in which this law was consolidated, discussions about the compulsory presence of music in Basic Education grew in line with the increase in scientific production regarding Music Education in Brazil. At times, when a field of knowledge increases its scientific productions, studies about the state of the art of that field are important, so that we can build reflections and 
paths for it.

It is worth noting that on May 10, 2016, with Resolution No. 2, issued by the National Board of Education-Chamber of Basic Education, this obligation was consolidated, regulating the presence of music in schools.

To investigate the scientific production in Music Education two journals of great importance in Brazil were chosen, the ABEM Journal and the Opus Journal.

The Brazilian Association of Music Education - ABEM (Website ABEM, 2018) is a scientific publication in Music Education that aims to disseminate the plurality of pedagogical-musical knowledge, whether scientific, through research reports, theoretical, through reflections on the new educational, political, and cultural paradigms, or of a historical nature, contextualizing current practices from a historical perspective. The journal is one of the publications of the Brazilian Association of Music Education (ABEM), a national non-profit organization, founded in 1991, with the purpose of bringing together professionals and organizing, systematizing and consolidating critical thinking, research, and performance in the field of musical education. ABEM promotes meetings, debates and the sharing of experiences among researchers, teachers, and students of Music Education from different levels and teaching contexts. According to the website of Brazilian Association of Music Education - ABEM:

"The main requirement for publication in the ABEM Journal is that the article represents, in fact, a scientific contribution regarding the relevance and pertinence of the subject addressed to the context and the moment; the reflection of the state of the art of knowledge in the area of the adopted theoretical-conceptual framework; the consistency of the development of the article in relation to the principles of scientific knowledge construction; clarity and conciseness of the implications of the work for the theory and/or practice of music education" (Website ABEM, 2018).

Another journal chosen in this research was Opus, linked to the National Association for Music Research and Postgraduate Studies (ANPPOM). Its main focus is to compose an overview of the most representative results of music research in Brazil. The magazine has a quarterly publication, maintaining high quality and regularity in its publications. Created in 1989, the Opus Journal aims to:

"disseminate the plurality of knowledge in music, considered practical, theoretical, historical, political, cultural and/or interdisciplinary aspects - always encouraging the development of new methodological perspectives. As it is the scientific journal of the National Association for Music Research and Postgraduate Studies (ANPPOM), its main focus is to compose a panorama of the most representative results of music research in Brazil" (Website OPUS, 2018).

Opus Journal disseminates the plurality of knowledge in music, considering practical, theoretical, historical, political, cultural, and/or interdisciplinary aspects, encouraging the development of new methodological perspectives.

It should be emphasized that before the emergence and consolidation of Law No. 11.769/2008 Musical Education already had a robust and growing production, regarding the delimitation of the area of knowledge and different conceptions (Brasil, 2008). However, it is understood that with the advent of legislation, there was an increase in research, enriching the scientific body of the area. Despite this panorama, even with the knowledge regarding the increase in the amount of research, the following questions arose: What subjects have been investigated in Music Education in Brazil in the last twelve years? What methodologies were used in these surveys? What are the theoretical references that underlie these investigations? What is the impact of these research on the Brazilian scientific scenario? Based on these questions, this research aimed to investigate the state of the art of musical education in Brazil in the last twelve years.

\section{Methodology}

The methodological design of the research was developed from data collection via Internet, proposed by Koch (1996), and data analysis according to the content analysis proposed by Moraes (1999).

\subsection{Internet Search}

Current research has resorted, for various reasons, to the use of the Internet, not only as a form of data collection but also for analysis procedures and other uses that virtuality can offer.

According to Freitas, Janissek-Muniz \& Mascarola (2004: p. 2), the "research process, in the traditional way practiced, is sometimes limited due to cost, time, geographical dispersion or labor intensity. Such barriers can be exponentially resolved using Internet technology."

In addition, there is a standardization of electronic addresses, as occurs in postal addresses, which facilitates the search. According to Marcuschi (2002), the "same individual may have a multiplicity of e-mail addresses depending on how many e-mail accounts or mailboxes he has opened. With today's facilities and multiplying business providers that allow 'free electronic accounts', most people use more than one email address" (Marcuschi, 2002: p. 37). 
The characteristics of Internet search allow a diversity of possibilities for access to various data, which facilitates displacement, allowing a wider coverage, at a lower cost. Therefore, its use in this research is justified, since the ABEM Journal (Website ABEM, 2018) and Opus (Website OPUS, 2018) were investigated, having a wide access to their websites.

Regarding the procedures for data collection via Internet, we used the one proposed by Koch (1996). The author proposes a taxonomy for the search area research area. In this research we used the processes proposed by Koch (1996), ie surfing, browsing and searching, from the journals of ABEM and Opus.

\subsection{Content Analysis}

After data collection by Internet, they were analyzed. According to Yin (2005), data analysis "consists of examining, categorizing, tabulating, testing, or otherwise recombining quantitative or qualitative evidence to address the initial propositions of a study" (Yin, 2005: p. 137). The analysis of the data from this investigation was performed through the use of content analysis proposed by Moraes (1999).

For the good progress of the research it was used the method proposed by Moraes (1999), which well explains the procedures of a qualitative analysis with the use of content analysis. According to the author, there are five steps to be taken, namely, information preparation, unitarization or transformation of content into units, categorization or classification of units into categories, description, and interpretation.

The procedure for this occurred from reading the data collected in the journals of Brazilian Association of Music Education - ABEM and Opus, deciding on which ones are effectively in accordance with the research objectives. Articles from both journals were organized in virtual folders, corresponding to volumes. Subsequently, information was extracted from the articles, such as title, abstract, keywords, authorship, theoretical framework, and methodologies. All these data were organized in tables, which allowed further analysis, increasing the obtaining of answers to the research questions. The preparation was an important stage of the research, because, as Moraes (1999) explains, even if the data on scientific production in Music Education in Brazil had already been possessed in the last twelve years, it needed to be prepared and transformed in order to undergo content analysis. After this procedure, it was possible to move (on) to unitarization.

Properly prepared virtual data from Internet research, they went through the process of unitarization, which consists of defining the units of analysis and content units that help in the construction of thematic categories or analysis that constitute the third stage of the process. This procedure was done by carefully reading all the material in order to define the units of analysis as well as the context units. According to Moraes (1999), the unit of analysis is the unitary content element that will be classified later. In this research, the units of analysis were the concepts or words that referred to the subject of the articles. Thus, the keywords were considered, being kept the virtual data from the Internet search or, in some moments, were divided into smaller units, depending on the situation, and presented in the virtual data collection. The context units, according to Moraes (1999), should set contextual boundaries for the articles, for the subjects dealt within them so that it is possible to perform - by scanning, relating and interpreting these units - the construction of the analysis categories. Moraes (1999) explains that while it is important that the definition of units of analysis have meaning in themselves, it must be ensured that a practice of content analysis defines, along with these units, another type of content unit, the context unit, which is a broader unit and serves as a reference to it, setting contextual boundaries to interpret it. Each context unit usually contains several record units, helping to avoid losing context by fully exploring its meaning. Once the units of analysis were identified and coded, they were categorized.

For Moraes (1999), the categorization process consists in the definition of analysis categories that are heterogeneous, exclusive, objective, relevant and appropriate. It consists of a cyclic return to the data, allowing the creation and refinement of analysis categories from the context units. The categorization allowed the definition of the element of analysis, in this case, the scientific production in Music Education in Brazil in the last twelve years, being called unit of analysis. For this definition the virtual data from the Internet research were kept or, in some moments, being divided into smaller units, depending on the situation presented in the virtual data collection. After performing these procedures, all materials were reread, units of analysis were identified and coded. After these codings, each unit of analysis was isolated, being rewritten and saved in virtual files, properly identified. In view of all these procedures, Moraes (1999) recommends that information has a complete meaning in itself, without the aid of additional information. The justification for this is due to the fact that in the later stages of the analysis these units were treated outside the context of the original message, being integrated into new sets of information and, therefore, must be understood and interpreted, keeping its original meaning (Moraes, 1999). All these characteristics of the categories prepared the description.

Once the categories were defined and the material of each one was identified, the results were communicated. The description is the first moment of this communication. For each category, a synthesis text was produced, but it has not 
yet covered the interpretations; this was for the later stage. It has, however, already contained broader descriptions depending on the levels of categorization. The organization of this description was determined by the category system built throughout the analysis. It was the moment, according to Moraes (1999), to express the meanings captured and intuited in the analyzed messages. This stage has produced comprehensive descriptions, seeking to focus on specific research questions on scientific production in music education in Brazil in the last twelve years, constituting a table with the categories of analysis and the synthesis texts, describing their scope and delimitation. The research subjects in Music Education in Brazil have been described in twelve years, the methodologies used in these research papers, the theoretical references that have grounded these studies, as well as the impact that they have had on the Brazilian scientific scenario. Through these description procedures the final stage, the interpretation, was reached.

The interpretation aimed at a proper understanding of the data. The task of this stage is to exercise the interpretation in greater depth, including the specialized literature and other research experiences, besides those lived by the researcher. This stage was composed of two strands. One of them, constituted by the theoretical foundation in Music Education (Kraemer, 2000) and the other by the Policy Cycle Approach, proposed by Bowe et al (1992) and Ball (1994), which resulted from an exploration of the meanings expressed in the categories of analysis, contrasted with this rationale (Moraes, 1999). The other strand was built on the basis of data and analysis categories. The theory emerged from information and categories. In this case, the very construction of the theory was interpretation. With all the data, they were organized in a notebook, constituting the Category Notebook (Wolffenbüttel, Riffatti \& Ramos, 2019).

Theorization, interpretation, and understanding constituted a circular movement in which, with each resumption of the cycle, it seeks to reach greater depth in the analysis (Moraes, 1999). At the end of the five steps, preparation, unitarization, categorization, description, interpretation, we proceeded to the elaboration of the answers to the research questions, treated at the end of this article.

\section{Theoretical Analytical-References}

To perform the data analysis concepts of Music Education and educational policies were used. When it comes to Music Education, Rudolf-Dieter Kraemer's epistemological conception of the study of Music Pedagogy greatly impacted the work. As for educational policies, the Policy Cycle Approach, constructed by Bowe et al (1992) and Ball (1994), supported the construction of the answers to the research questions.

Kraemer (2000), in his studies on the dimensions and functions of pedagogical-musical knowledge, discussed Musical Education from the paradigm that makes it explicit as an area linked to several others. The author explains that the object of the study of Music Pedagogy is the transmission and appropriation of music, a process that involves the relationships that are established between people and music, and that occurs in different times and spaces.

Starting from the conception that the Pedagogy of Music always deals with the relationship between music and people, the constitution of the pedagogical-musical knowledge, for Kraemer (2000), will be based on an interweaving of several areas, especially the Human Sciences and Pedagogy of Music, to investigate its object. In his studies, the author explains how the areas of Psychology, Sociology, History, and Philosophy, for example, often deal with the same object of study as Pedagogy, a fact that occurs with learning, which is investigated from different problems and methods in these different areas and in Pedagogy.

Kraemer (2000) explains that the particularity of pedagogical-musical knowledge lies at the intersection of pedagogical ideas marked by the humanities, oriented by musical culture, and aesthetic musical ideas (Kraemer, 2000). The studies by Kraemer (2000) allow a broad approach to think the pedagogical-musical processes, understanding them not as a mere matter of enjoyment of musicological contents and specific cognitive abilities, but as a complex relationship between people and music, which happens due to social, psychological, cognitive and historical factors, among others.

Another theoretical-analytical framework used in this research was the Policy Cycle Approach. In their studies, Bowe et al (1992) investigated educational policies in England from a cyclical notion. The authors initially aimed to bring in their work the transformations of a national curriculum policy in the school environment and to characterize the educational policy process broadly covering both micro and macro aspects. In their studies, the authors have characterized three arenas for the political process: the arena of proposed policy, the arena of politics in fact and the arena of politics in use.

The arena of proposed policy consists of the stage in which a law is discussed, its formulation meets the intentions of governments, school demands, the intentions of authorities, among other aspects. The arena of politics in fact is constituted by the political and legislative texts that shape the proposed policy. Thus, the third proposed arena, the arena of politics in use, constitutes the institutional practices and discourses arising from the implementation of the laws. Thus, at this stage of the Policy Cycle Approach, the authors present the contexts of influence, political text, and political strategy. 
In 1994, Ball, deepening his studies on the Policy Cycle Approach, expanded it into two more contexts, effects and political strategy. Ball (1994) explains that the context of political effects can be specific or general so that it can arise in both macro and micro contexts. This context of effects concerns the effects of the context of practice and application, which do not always meet the context of the political text. This illustrates how the approach can be an important tool for analyzing educational policies at its macro and micro levels. The context of political strategy is that which concerns how actions will take place from the effects of a policy. If a law gives rise to inequality, a political strategy is needed to exclude these effects. The strategy may be the modification of a law, or even its exclusion, both to address inequalities and to extend the benefits of its implementation. Thus, according to Ball's proposal (1994), the five contexts of a policy are the context of influence, political text, practice, effects, and political strategy.

The Policy Cycle Approach, proposed by Bowe et al (1992) and Ball (1994), is a look at policy research and allows a broad understanding of their application and operation, not a way to illustrate how all of the policies work. Likewise, it is not simply a matter of establishing a temporal and continuous characterization of the political process, but rather of understanding how these contexts can influence and function within educational policies.

\section{Results e Discussions}

From the data collection, 305 articles were found, 265 from ABEM Journal and 40 from Opus Journal. After analysis, the results were organized into four categories in order to answer the research questions, namely: subjects, methodologies and theoretical references.

\subsection{Subjects}

This category refers to the subjects that are dealt with in the articles analyzed in the journals of ABEM and Opus. In all, 17 subjects were found from which, in these journals, the knowledge in Music Education has been built. Table 1, Article Subjects, illustrates the subjects found and their implications:

Table 1. Article Subjects

\begin{tabular}{lllll}
\hline & \multicolumn{1}{c}{ Subjects } & ABEM & Opus & Total Articles by \\
& & Journal & Journal & Subject \\
\hline 1 & Academic Training & 48 & 6 & 54 \\
2 & Pedagogical Practices and Teaching & 48 & 5 & 53 \\
3 & Music Education & 30 & 7 & 37 \\
4 & Learning & 30 & 4 & 34 \\
5 & Musical Instruments Teaching and Learning & 18 & 3 & 21 \\
6 & State of Art & 15 & 2 & 17 \\
7 & Teaching Practices Repertoire & 15 & 1 & 16 \\
8 & Policy & 12 & 2 & 14 \\
9 & Music Education History & 12 & 2 & 14 \\
10 & Information and Communication Technologies and Distance & 11 & 2 & 13 \\
& Education & & & 12 \\
11 & Insertion of Music Into Basic Education Curriculum & 7 & 5 & 9 \\
12 & Professionalization of the Music Teacher & 8 & 1 & 6 \\
13 & Inclusion of Students With Special Needs & 6 & - & 2 \\
14 & Selective Process & 2 & - & 1 \\
15 & Evaluation of the Pedagogical-musical program & 1 & - & 1 \\
16 & Religion & 1 & - & 305 \\
17 & Teaching Materials & 1 & - & \\
\hline & Total Articles & 265 & 40 & \\
\hline
\end{tabular}

Source: authors, 2018. 
The subjects found in greater quantity in both magazines were Academic Training, Pedagogical Practices and Teaching, Music Education and Learning. Table 2, Most Frequent Subjects, summarizes the frequency of the articles included in these subjects.

Table 2. Articles with the Most Frequent Subjects

\begin{tabular}{llll}
\hline \multicolumn{1}{c}{ Subjects } & ABEM & Opus & Total Articles by Subjects \\
& Journal & Journal & \\
\hline Academic Training & 48 & 6 & 54 \\
Pedagogical Practices and Teaching & 48 & 5 & 53 \\
Music Education & 30 & 7 & 37 \\
Learning & 30 & 4 & 34 \\
\hline Total Articles & 156 & 22 & 178 \\
\hline
\end{tabular}

Source: authors, 2018.

Academic Training, Pedagogical Practices and Teaching, Music Education and Learning present in the articles of ABEM and Opus journals deal with issues of extreme relevance to Music Education.

In the subject of the Academic Training there are articles about

"the processes that involve the academic formation of music educators. This category includes articles that deal with the relationship between teacher training and the pedagogical practice of these teachers, the role of teacher training, which is understood by teacher education and music teachers among other aspects that constitute the training of the music teacher. It also encompasses articles discussing the continued teacher training" (Wolffenbüttel, Riffatti \& Ramos, 2019: p. 1).

After the consolidation of Law No. 11.769/2008 there was an expansion in undergraduate music courses in Brazil. Research developed by Vianna Filho (2016) shows the expansion of undergraduate music courses in Rio Grande do Sul - which is one of the states in Brazil - in the last twelve years, and the creation of five new courses in the field after the referred law. In 2016, the resolution on the Guidelines for the operationalization of music teaching in Basic Education was approved, which already mandates colleges and universities to expand their degrees in music and Public Schools Network to create more public tenders for graduates in music.

In a survey conducted with 215 graduates between 2009 and 2014 from colleges and universities of Paraná - another state of Brazil - Gomes (2016) found that 33\% of graduates work in Basic Education at public schools, from which $12.5 \%$ work as government employees, hired after going through public tenders and $11.5 \%$ as government employees hired with a time-limited contract. The low insertion rate of music graduates in primary education has been pointed out for some time in research in Music Education (Penna, 2002) and is, among other factors, due to low pay and difficult working conditions, as well as a gap between theory and practice recurrently criticized in teacher education. The low insertion of graduates has shown the importance of always thinking and rethinking the training of music teachers, so that they can occupy the spaces in public schools and, thus, Music Education can occur effectively.

Thus, Academic Training is presented as a theme that emerges within what Ball (1994) characterizes as the context of the effects of a policy, and may also infer in the context of practice (Ball, 1994) when this production is diffused and can support the construction of undergraduate music courses and the practices of graduates.

Pedagogical Practices and Teaching include articles that discuss how music teachers' pedagogical practices occur. Much of the scientific production investigated focuses on the pedagogical-musical processes, from the perspectives of teaching and learning. The works that address this theme

"involve questions about the pedagogical practices of music educators, both in the classroom and in any other place where Music Education may occur. Regarding how teachers and students perceive the practices developed by educators -, reflections on teaching practice and also on different methodological and teaching processes applied, tested, and criticized by teachers and researchers. Psychological, social, as well as other factors that may interfere with teaching in the teaching-learning process" (Wolffenbüttel, Riffatti \& Ramos, 2019: p. 1).

The Music Education theme is characterized by studies that treat Music Education as: 
"a field of knowledge, epistemological studies, about nature, method and object of study of Musical Education. Influences from other fields of knowledge in Music Education, interdisciplinarity in Music Education, notes on the possibilities of intersection among Music Education and other areas such as Ethnomusicology, and the contributions of these other fields to the study object of Music Education. Some studies about the conceptions of those involved in the pedagogical-musical process about what is Music Education" (Wolffenbüttel, Riffatti \& Ramos, 2019: p. 2).

Subsequently, the theme of Learning includes "articles that deal with learning processes, both in teaching-learning and self-learning relationships. Factors that interfere with learning, which may be psychological, social, and others" (Wolffenbüttel, Riffatti \& Ramos, 2019: p. 1). Understanding Musical Education from an epistemological point of view, as proposed by Kraemer (2000), and also thinking about the constitution of pedagogical-musical knowledge, based on relationships between people and music, it is important to seek solid knowledge and help in pedagogical practices, in teaching-learning relationships (in order) to know the different processes of teaching and learning music and the relationships between them.

Another theme present in both journals is Music Instruments Teaching and Learning, founded in 21 articles that deal with "technical and musical improvements specifically in musical instruments for the training of instrumentalists and performers and their learning and teaching processes in instrumental practice, articles on skills developed for musical performance improvement and public performances" (Wolffenbüttel, Riffatti \& Ramos, 2019: p . 1).

In this theme, eight articles focused on teaching singing, which is an important instrument for music teachers who have entered public education and deal mainly with the lack of musical instruments in schools. The other articles deal with various research papers on the teaching and learning of musical instruments, such as drums and piano, among others.

Research regarding the State of Art in Music Education also has a significant number of publications, totaling 17 published articles. In these research papers we observe articles that deal with

"scientific production in Music Education in Brazil. Many studies evaluate, measure, analyze, and criticize scientific production in Music Education fall into this category. Also in this category are studies that verify and analyze the presence of various themes in scientific production and point out trends, weaknesses, and advances in the field, as well as their impacts on policies and pedagogical-musical, and cultural practices" (Wolffenbüttel, Riffatti \& Ramos, 2019: p. 2).

Similarly to the research presented in this article, the studies on the State of Art help us to systematize and think about the production of knowledge in Music Education, providing the field with a reflection about itself in order to point out advances and weaknesses.

The Policy research amounted to 14 publications. This theme includes works

"that deal with educational and cultural policies and their implications for Music Education. They also deal with the relationship between the struggle of the working class of Musical Educators with government agencies, with a view to establishing the field in Basic Education. Articles that relate to the actions, movements, and political strategies of Music Education are also included here" (Wolffenbüttel, Riffatti \& Ramos, 2019: p. 2).

It is noticeable that after the approval of Law No. 11.769, studies emerged verifying how the process of implementation of the law occurs, confirming what Ball (1994) characterizes as the context of the effects of policy. These same studies, besides the scientific production in Music Education as a whole, are of great importance for the execution of the policies that seek the teaching of music in schools, also in order to think of possible alternatives for improving or maintaining these policies, trying to minimize the dichotomies between the context of the political text and the context of practice (Ball, 1994).

The Decree No. 5.800, of June 8, 2006, created the Universidade Aberta do Brasil (Open University of Brazil) (1). In view of this event, it is possible to observe in the scientific production of the investigated journals the emergence of investigations that relate to this fact. Thus, the contexts of effects and practice (Ball, 1994) are established and substantiate this theme. Also, studies that address teacher education policies in Brazil, such as the Institutional Teaching Initiation Scholarship Program (Pibid) and Prodocence (Montandon, 2012) (2), and analyze the positive aspects and impacts of policies were found in this research about the state of the art in the articles. They also corroborate, as proposed by Kraemer (2000), articles related to historical pedagogy. The relevance of these works is understood, in agreement with Kraemer (2000). For the author, "the description of the musician-educational practice is open, which is not only thinking, but also carried out. In addition, the historical and political consideration of a period provides a model of a dominant argument, an economically conditioned pedagogical musician-cultural form" (Kraemer, 2000: $\mathrm{p}$. 54).

It is understood that studies on educational policies, musical education and the relationships that are established in this process can contribute to the understanding and study of the functioning of educational policies. 
Also present in the researched production are several articles that deal with the relations between the musical repertoires present in the pedagogical-musical processes and their relations with learning and musical meanings. In this subject there are several "research papers and works on the musical tastes of students at different levels of education, as well as which repertoires are present in the teachers' practices in different educational spaces, and the dichotomy that exists in the pedagogical practice between classical and popular repertoire in Musical Education" (Wolffenbüttel, Riffatti \& Ramos, 2019: p. 3).

Another subject presented in the verified journals involves Information and Communication Technologies (ICTs) and Distance Education (DE), which are based on "studies on the relationship between Information and Communication Technologies and Music Education. Regarding aspects such as increased ease of access to music and technologies as a pedagogical resource. Also on the training of music teachers in the Distance Education modality" (Wolffenbüttel, Riffatti \& Ramos, 2019: p. 2).

Regarding research on the presence of articles about the relationship between Distance Education and Music Education, Colabardini \& Oliveira (2016) point out the need to undertake more studies that discuss the possibilities for the training of music teachers through ICTs pointing mainly reflections about the real validity of the use of ICTs, since the initial training of teachers. The "growing presence of new technological resources in music lessons, the need for better understanding of the teaching and learning processes present, as well as the appropriate training for teachers in the field" (Colabardini \& Oliveira, 2016: p. 150).

The Insertion of Music in Basic Education is another theme present in the scientific production in Music Education, and concerns the articles that deal specifically with the presence of music and the problems faced by the area for this inclusion in Basic Education in the period after Law No. 11.769/2008. This subject, which has added 12 articles in the journals, is limited by how occurs "the insertion of music in basic education, who is occupying the spaces of music educator in schools, specific problems of this space that is to be occupied by music educators even if he or she is not treated exclusively in this category" (Wolffenbüttel, Riffatti \& Ramos, 2019: p. 2).

An example of this theme is the article "Musical Education in schools of Costa Verde, Sul Fluminense: problematizing possibilities for the implementation of Law 11.769/2008" (Requião, 2013). The research was developed from extension activities, investigating the conceptions of schools about Music Education and what would be the profile of the music teacher in the process of "understanding the challenges ahead for Music Education in schools to become a reality" (Requião, 2013: p. 1).

The History of Music Education was the subject that had an incidence of fourteen articles in the reviewed journals. According to Kraemer (2000), history is composed of "historical research and writing" (Kraemer, 2000: p. 54). For the author (2000), understanding its perspective on a complex thinking and dependent on what is the construction of knowledge in Music Education, then, the story stands as an important aspect of Music Education. In the production of journals, there are articles that deal with "The insertion of the transverse flute in teaching in Portugal from 1750 to 1850" (Andrade, 2007), until the history of Music Education in Brazil. In this sense, the work of Fonterrada (2007) is highlighted, for example, from which

" a historical review of Brazilian music education is conducted over the last fifty years, pointing out how it has weakened in school, shown good participation in cultural and social projects, and strengthened with class associations and postgraduate courses. It is pointed out that the classical methods of music education of the early twentieth century were answers to the needs of their time" (Fonterrada, 2007: p. 27).

From the research that investigates Music Education's historical aspects, the author (Fonterrada, 2007) proposes answers to the needs verified in Music Education to deal with contemporary problems. This subject is delimited by "Research on Historical Aspects of Musical Education" (Wolffenbüttel, Riffatti \& Ramos, 2019: p. 3).

The Professionalization of the Music Educator is another very important subject for the area - at a time when there is a low presence of music graduates in schools - so that aspects, skills, competences and goals are fundamental for a music educator to establish in his work, with a view to developing it effectively and occupy the school spaces of public education. In this theme one also perceives an important connection from the field of study between the knowledge coming from the teacher's practices and the scientific knowledge produced. Professionalization is one aspect of teacher education; but not only understood as a delimitation, given the theme of the present research, which defines the presence of academic theme and continuing education for analysis, but as a process that begins in the teacher's family and extends throughout schooling. As academic background and reflective practice, as well as the influence of these factors on the practices and conceptions about teachers' music education. The presence of this theme, found in the data collection in this investigation, was characterized by studies on the 
"processes that can involve both professionalism professional culture acquired by the teacher, i.e. the teacher's own knowledge and the construction of professional skills, as well as professionalism professional identity, obtaining professional status and social recognition and its implications to the constitution of the music educator in his or her practices and conceptions about Music Education" (Wolffenbüttel, Riffatti \& Ramos, 2019: p. 1).

In addition to the subjects previously presented, Inclusion of Students with Special Needs, Selective Processes, Evaluation of the Pedagogical-musical program, Religion and Teaching Materials were also among the research undertaken and published. However, they were found only in the ABEM Journal. Table 3 of the Articles with Less Frequent subjects presents the synthesis of this appearance.

Table 3. Articles with Less Frequent Subjects

\begin{tabular}{llll}
\hline \multicolumn{1}{c}{ Subjects } & ABEM & Opus & Total Articles by Subjects \\
& Journal & Journal & \\
\hline Inclusion & 6 & - & 6 \\
Selective Processes & 2 & - & 2 \\
Evaluation of the Pedagogical-musical program & 1 & - & 1 \\
Religion & 1 & - & 1 \\
Teaching Materials & 1 & - & 1 \\
\hline Total Articles & 11 & - & 11 \\
\hline
\end{tabular}

Source: authors, 2018.

The Inclusion of Students With Special Needs subject appeared in 6 articles and with an increase especially in 2016 and 2017 , being 4 of these articles published only in this period.

The Selective Processes subject, with the presence of two articles, focuses on the profile of students applying for music schools and the question of specific skills tests required to enter music courses at universities. The Evaluation of the Pedagogical-musical program theme, with an article written by França (2010), discusses what is evaluated in the tests of Music courses. The aspect of Religion is brought into focus by Matinoff (2010), from a bibliographical research on the relationship between gospel music, the media, and society. Finally, in Teaching Materials, Oliveira (2007: p. 1) investigated the "conceptions that underlie the use of didactic materials by music teachers in their musical pedagogical practices".

\subsection{Methodologies}

When analyzing ABEM and Opus journals regarding methodological procedures, we found mentions of 47 different types used in research in Music Education. Table 4 below presents the methodologies found in the articles of the ABEM and Opus journals. 
Table 4. Methodologies of the Articles

\begin{tabular}{|c|c|c|c|}
\hline & Methodologies & $\begin{array}{l}\text { ABEM } \\
\text { Journal }\end{array}$ & $\begin{array}{l}\text { Opus } \\
\text { Journal }\end{array}$ \\
\hline 1 & Essay & 67 & 9 \\
\hline 2 & Literature Review & 31 & 10 \\
\hline 3 & Case Study & 29 & 2 \\
\hline 4 & Experience Report & 17 & 2 \\
\hline 5 & Qualitative Research, Exploratory Interview Research & 15 & 2 \\
\hline 6 & Bibliographic Research & 14 & 2 \\
\hline 7 & Narrative Biographical Research & 8 & 2 \\
\hline 8 & Field Research & 8 & 1 \\
\hline 9 & Documentary Research & 7 & 7 \\
\hline 10 & Survey & 7 & - \\
\hline 11 & Action Research & 6 & 1 \\
\hline 12 & Ethnographic Research & 5 & 1 \\
\hline 13 & Focus Group & 4 & - \\
\hline 14 & Oral History & 4 & - \\
\hline 15 & Bibliografic and Documentary Research & 4 & - \\
\hline 16 & Mapping & 3 & - \\
\hline 17 & Speech Analysis & 2 & - \\
\hline 18 & Rhetorical Analysis & 2 & - \\
\hline 19 & Quantitative Research & 3 & - \\
\hline 20 & Experimental Research & 2 & - \\
\hline 21 & Qualitative, Exploratory with Observations, Interviews & 2 & - \\
\hline 22 & Systemic Analysis & 1 & - \\
\hline 23 & Systemic Evaluation & 1 & - \\
\hline 24 & Investigative Cadences & 1 & - \\
\hline 25 & Interviews & 1 & - \\
\hline 26 & Academic Motivation Scale & 1 & - \\
\hline 27 & Statistical-Catalog & 1 & - \\
\hline 28 & Comparative Study with Product Analysis & 1 & - \\
\hline 29 & Interview Study & 1 & - \\
\hline 30 & Cultural Studies, Interview Collection and Observation & 1 & - \\
\hline 31 & Discussion Group & 1 & - \\
\hline 32 & Exploratory Opinion Investigation & 1 & - \\
\hline 33 & Didactic Dialectical Method & 1 & - \\
\hline 34 & Participant Observation & 1 & - \\
\hline 35 & Cartographic Research & 1 & - \\
\hline 36 & Descriptive Research with Comparative Analysis & 1 & - \\
\hline 37 & Ethnographic Research with Semiotic Analysis & 1 & - \\
\hline 38 & Ex Post Facto Research & 1 & - \\
\hline 39 & Exploratory Research & 1 & - \\
\hline 40 & Genealogy Research & 1 & - \\
\hline 41 & Participant Research & 1 & - \\
\hline 42 & Qualitative and Quantitative Research & 1 & - \\
\hline 43 & Quantitative Research, Descriptive with Questionnaires & 1 & - \\
\hline 44 & Qualitative Descriptive with Interview & 1 & - \\
\hline 45 & Qualitative, Exploratory with Collection by Questionnaires & 1 & - \\
\hline 46 & Interval Awareness Test & 1 & - \\
\hline \multirow[t]{2}{*}{47} & Mixed Methods & - & 1 \\
\hline & Total Articles & 265 & 40 \\
\hline
\end{tabular}

Source: authors, 2018.

Among the 47 types of methodological procedures, the five with the highest incidence were essay, literature review, case study, experience report, and qualitative, exploratory research with interviews, with an incidence of 76, 41, 31, 19, and 17, with appearances each, as shown in table 5. 
Table 5. Methodologies With Higher Incidence in the Articles

\begin{tabular}{lllll}
\hline \multicolumn{2}{l}{ Methodologies } & ABEM Journal & $\begin{array}{l}\text { Opus } \\
\text { Journal }\end{array}$ & Total \\
\cline { 2 - 5 } 1 & Essay & 67 & 9 & 76 \\
2 & Literatura Review & 31 & 10 & 41 \\
3 & Case Study & 29 & 2 & 31 \\
4 & Experience Report & 17 & 2 & 19 \\
5 & Qualitative Research, Exploratory with Interviews & 15 & 2 & 17 \\
\hline
\end{tabular}

Source: authors, 2018.

According to Garcia (2016), it is a difficult task to classify research on methodological aspects. According to the author, depending on the authors' various propositions, the criteria for research classification may vary. Garcia (2016) explains from other authors that these classifications are given in relation to research designs. According to the author, these designs can be classified "with or without groupings" (Garcia, 2016: p. 292). To exemplify these classifications, Garcia (2016) presents the propositions of authors who classify research without grouping and more broadly. Similarly, there are authors who use clusters to classify research in their methodological aspects. In this way it is considered nature, objectives, procedures and research object for a more descriptive and extensive classification of the procedures adopted in specific groupings. It is classified more generally by specifying generally the type of material to be analyzed. The scientific production in Music Education in Brazil in the last twelve years illustrates a variety of instruments or methodological procedures explained in these articles.

The theoretical and methodological variety presented in the verified journals goes beyond the possibility of a methodological classification from a rigid theoretical, methodological or epistemological perspective. This variety also represents Music Education as an area of knowledge that builds and shares its object of study, as proposed by Kraemer (2000), with other areas of the humanities in a complex way and with a wide range of methodological instruments. It is also important to note that often, even from different theoretical conceptions, many methodological instruments are similar between different research studies or even used in the same way. However, from different theoretical-epistemological conceptions, new problematizations and tensions of the object of Music Education are built, making it complex.

In addition, the fact that the methods used in Music Education's research have diversified in the last twelve years, appearing theoretical-methodological conceptions that were not presented in previous articles.

Among the methodologies found in greater number are articles from essays, bibliographic reviews, case studies, experience reports, as well as qualitative, exploratory, and interviews.

According to Meneghetti (2011: p. 321), the essay constitutes the "permanent relationship between subject and object, a coming to be constituted by the interaction of subjectivity with the objectivity of those involved". Another definition proposed by Barros (2011), which dialogues with Meneghetti (2011), presents the theoretical essays as "interpretations that the author offers to the reader, thus seeking a starting point for dialogue and debate" (Barros, 2011: p. 334). The author adds that the theoretical essay "has, therefore, a strongly dialogical nature, is a process of meaning construction in which those involved are co-authors of a content negotiated and made effective in the act of textual formulation and reception" (Barros, 2011: p. 334 ).

In this research scientific and theoretical essays were classified based on the authors' definitions, articles that compare different teaching approaches, from a theoretical framework that relates concepts that can help the thoughts and knowledge in Music Education; that deal with ABEM and are written by researchers who have an "inside the institution" look, who discuss issues that help practices in Music Education, based on assumptions presented by the authors; and texts that propose diverse reflections on theoretical nature about the Music Education. Some of these texts are presented as essays in the abstracts, others were classified as essays because they are not presented as research results, literature reviews or experience reports. In the investigated production, ( 76 articles) were found that have these characteristics, 67 in ABEM Journals and 9 in Opus Journals. For example, there are texts such as Caregnato's (2011), which discusses two rhythm teaching strategies based on Piaget's epistemological-genetic theories.

There are also a large number of articles from Bibliographic Reviews, which could also be classified as Literature Reviews. According to Garcia (2016) Bibliographic Reviews are "a very important part of any research, as it is the theoretical foundation, the state of the art of the subject being researched" (Garcia, 2016: p. 292). There were several 
articles summarizing these reviews on certain subjects in texts. Some articles bring in their summaries the specification of the objective of presenting the literature review made in research and others seek within the scientific production the occurrence of a specific subject to verify the state of the art. There are 41 Bibliographic Reviews and also 3 Bibliographic Searches. As Garcia (2016) shows us, despite the similarities of the material treated, the difference between the two is that in the Bibliographic Reviews we seek a "survey of the state of the art of that content" (Garcia, 2016: p. 293), and in Bibliographic Research

"the researcher must propose a research problem and a goal that are in line and that the answer that will be sought is in the books, articles, thesis, dissertations and also with the advent of the internet a lot of data can be searched, or even the answer found is the opposite of what is in the books and articles" (Garcia, 2016: p. 292).

Another type of research presented in journals, which, according to Gil (2008), resembles Bibliographic Research, is Documentary Research:

"The only difference between them is in the nature of the sources. While bibliographic research uses fundamentally the contributions of various authors on a given subject, documentary research uses materials that have not yet received analytical treatment, or that can still be reworked according to the research objectives" (Gil, 2008: p. 51).

About case studies, Alves-Mazzotti (2006) explains that they are recurrent by a common thought that they are easier to apply by studying a specific unit of context.

\subsection{Theoretical References}

During the research process, regarding the search for the theoretical references that underlie the scientific production in Music Education, tables were elaborated in which the names of the articles were inserted and alongside the references that supported the constitution of each text were indicated, as well as the concepts used from these references.

In seeking a quantitative systematization of these data, for further qualitative analysis, it was found that few theoretical references were repeated in different research studies, and when this occurred, it occurred in small quantities, often in different groupings of reference, considering that most of the texts did not bring only one author, work or concept as a reference. Thus, the theoretical references that underlie scientific production also come from various areas of knowledge.

One of the references presented is Bourdieu theory, which originates in Sociology's studies. Similarly, articles were found based on Piaget's studies, with their epistemological-genetic theories, interlocution with Education, Biology and Psychology mainly.

The foundations originated from the Music Education presented with references to the studies of Kraemer, Swanwick, Koellreuter, and Dalcroze, among others. This vast diversity of authors represents both a solid constitution of a theoretical field of Music Education and this constitution as a result of an object shared with various theories of the human sciences, as stated by Kraemer (2000). The reflection of this complexity that constitutes the pedagogical-musical knowledge is presented in the theoretical references and in the conceptions about the methodological procedures adopted in equal intensity, becoming even more diverse over the years.

\section{Conclusions}

The end of this research, which aimed to investigate the state of art of Music Education in Brazil in the last twelve years, brought many understandings about Music Education in Brazil. This understanding was possible due to a systematic and careful analysis, having the following questions: What subjects have been investigated in Music Education in Brazil in the last twelve years? What methodologies were used in these surveys? What are the theoretical references that underlie these investigations? What is the impact of these research on the Brazilian scientific scenario? Therefore, the answers to the guiding questions of the investigation follow.

Regarding what has been investigated in Music Education in Brazil in the last twelve years, 17 subjects were found: Academic Training, Pedagogical Practices and Teaching, Music Education, Learning, Musical Instruments Teaching and Learning, State of Art, Teaching Practices Repertoire, Policy, Music Education History, Information and Communication Technologies and Distance Education, Insertion of Music Into Basic Education Curriculum, Professionalization of the Music Teacher, Inclusion of Students With Special Needs, Selective Process, Evaluation of the Pedagogical-musical program, Religion and Teaching Materials. It is noted that these subjects appear most often related to problems of the insertion of music in schools. Many articles have in their abstract the intention to contribute to the implementation of Law No. 11.769/2008, something that is also illustrated from subjects such as policies and insertion of music in Basic Education, for example. Out of these 17 subjects, the most common are Academic Training, Pedagogical Practices and Teaching, Music Education and Learning.

Regarding the question about which methodologies are based on research in Music Education in Brazil, in view of the 
collection and analysis of 305 articles published in the Brazilian Association of Music Education - ABEM and Opus journals, 47 methodological procedures that have been adopted in the research were detected, including academic motivation scale, action research, bibliografic and documentary research, bibliographic research, cartographic research, case study, comparative study with product analysis, cultural studies, interview collection and observation, descriptive research with comparative analysis, didactic dialectical method, discussion group, documentary research, essay, ethnographic research, ethnographic research with semiotic analysis, ex post facto research, experience report, experimental research, exploratory opinion investigation, exploratory research, field research, focus group, genealogy research, interval awareness test, interview study, interviews, investigative cadences, literature review, mapping, mixed methods, narrative biographical research, oral history, participant observation, participant research, qualitative and quantitative research, qualitative descriptive with interview, qualitative research, exploratory interview research, qualitative, exploratory with collection by questionnaires, qualitative, exploratory with observations, interviews, quantitative research, quantitative research, descriptive with questionnaires, rhetorical analysis, speech analysis, statistical-catalog, survey, systemic analysis and systemic evaluation.

Of these methodological procedures, most investigations have adopted the methodologies like essay, literature review, case study, experience report, and the qualitative research, exploratory interview research.

In this sense, it is emphasized that the particularity of the pedagogical-musical knowledge occurs in the epistemological imbrication in order to analyze the object of the area. As discussed in the analysis, the wide variety of conceptions about the adopted procedures meets the great variety of scientific areas that have instrumentalized Music Education, for the construction of its object of study. It is understood that it would be very interesting a future research that seeks to trace a historical trajectory in this sense and verify how these procedures, often quite similar, are treated in different ways, from different epistemological positions, and how they build the field of Music Education and its object.

About the theoretical references used in the investigated research, it was verified that they are also different, according to the problems that are considered in the research. The construction of the object of Music Education, in this sense, occurs from the contexts in which an area can occur, and is involved in the relationship between people and music as a learning and teaching process. Being a scientific production in Music Education focused on the effectiveness of music teaching in various spaces, according to the problems that are presented for its effectiveness, both in micro and macro contexts, also with the researcher's theoretical positioning, different instrumentalizations, both methodological and theoretical approaches are adopted. This enables the construction of openly delimited pedagogical-musical flavors that come from different contexts, from both analysis and analytics. It is noteworthy that most research does not use only one work or author as a theoretical framework. By dealing with such diverse contexts, the scientific production in Music Education has been richly constructed, enabling the democratization and sharing of scientific knowledge in Music Education.

Regarding the impacts of scientific production on the Brazilian scientific scenario, it is pointed out the consolidation of a variety of discussions that form the object of Music Education, in addition to the construction of the area as a scientific field, which deals with problems related to the specificities of the musical processes, teaching and learning music, but also discusses these processes in various spaces and their relationships with different factors such as policies and training of professionals.

During the reading of the analyzed material, it was evident the existence of research dealing with the historical trajectory of ABEM constitution and practices. This institution does not only function as a vehicle for the dissemination of scientific knowledge produced in higher education institutions. ABEM also performs integration functions between the construction of scientific knowledge in Music Education, with the school contexts of teaching, providing teaching materials, continuing education courses for teachers, symposiums and regional and national events. The institution also played an important role in the construction of the current legislation for the teaching of music in schools, enabling the construction of political texts to support the context of the practice of public policies in Music Education in Brazil. Currently, ABEM also functions as the largest vehicle for scientific dissemination in Music Education in Brazil, being indispensable for the construction of the scientific field and a large corpus of published productions, including international publications.

In concluding this research and making its results public, it is pointed out the importance of other investigations being carried out in the field of Music Education, deepening on the impacts that the publications of both ABEM and Opus journals have had on Brazil and reflected on international level.

\section{Acknowledgements}

Eduardo Filipe Albrecht Lassig. Rio Grande do Sul Research Support Foundation (FAPERGS), National Council for Scientific and Technological Development (CNPq). 


\section{References}

Alves-Mazzotti, A. J. (2006). Usos e abusos dos estudos de caso. Cad. Pesqui, 36(129), 637-651. https://doi.org/10.1590/S0100-15742006000300007

Andrade, A. (2007). A inserção da flauta transversa no ensino, em Portugal de 1750 a 1850 . Revista da ABEM. Londrina: ABEM, 15(17). Retrieved from http://www.abemeducacaomusical.com.br/revistas/revistaabem/index.php/revistaabem/article/view/276.

Ball, J. S. (1994). Educational reform: a critical and post structural approach. Buckingham: Open University Press.

Barros, K. S. M. (2011). Réplica 1: O que é um ensaio? Revista de Administração Contemporânea. Rio de Janeiro, RJ: ANPAD., 15(2). https://doi.org/10.1590/S1415-65552011000200011

Bowe, R. et al. (1992). Reforming education and changing schools: case studies in policy sociology. London: Routledge.

Brasil (2008). Law No. 11.769, from August 18. Retrieved from http://www.planalto.gov.br/ccivil_03/_ato2007-2010/2008/lei/111769.htm

Caregnato, C. (2011). Estratégia métrica vs estratégia mnemônica: Posições contrastantes ou complementares no ensino de ritmo? Revista da ABEM. Londrina: ABEM., 19(25). Retrieved from http://abemeducacaomusical.com.br/revistas/revistaabem/index.php/revistaabem/article/view/192

Colabardini, C. M. C., \& Oliveira, M. R. G. O. (2016). A educação musical a distância nas páginas da ABEM: Breve discussão sobre artigos publicados até 2015. Revista NUPEM. Campo Mourão, PR: ABEM., 8(15). Retrieved from http://revistanupem.unespar.edu.br/index.php/nupem/article/view/156

Ferreira, N. S. de A. (2002). As pesquisas denominadas “estado da arte". Educação \& Sociedade, XXIII(79), $257-272$. https://doi.org/10.1590/S0101-73302002000300013

Fonterrada, M. T. O. (2007). Diálogo interáreas: o papel da educação musical na atualidade. Revista da ABEM. Londrina: ABEM., 15(18). Retrieved from

http://abemeducacaomusical.com.br/revistas/revistaabem/index.php/revistaabem/article/view/271

França, C. C. (2010). Dizer o dizível: Avaliação sistêmica em música na escola regular. Revista da ABEM. Londrina: ABEM., 18(24). Retrieved from http://abemeducacaomusical.com.br/revistas/revistaabem/index.php/revistaabem/article/view/208.

Freitas, H., Janissek-Muniz, R., \& Mascarola, J. (2004). Uso da Internet no processo de pesquisa e análise de dados. Associação Nacional de Empresas de Pesquisa. Anais... São Paulo: ANEP. Retrieved from http://www.ufrgs.br/gianti/files/artigos/2004/2004_147_ANEP.pdf

Garcia, E. (2016). Pesquisa Bibliográfica vs revisão bibliográfica: Uma discussão necessária. Revista Línguas e Letras. Cascavel, PR: UNIOESTE., 17(35). Retrieved from http://e-revista.unioeste.br/index.php/linguaseletras/article/view/13193

Gil, A. C. (2008). Métodos e técnicas de pesquisa social. São Paulo: Editora Atlas.

Gomes, S. M. (2016). A inserção Profissional de licenciados em Música: um estudo sobre egressos de instituições de ensino superior do estado do Paraná (Doutorado). Porto Alegre: Universidade Estadual do Rio Grande do Sul.

Koch, T. (1996). Internet search services. (Translation of a paper given at: "Further on the way to the virtual library! Libraries are using the Internet". Erste INETBIB-Tagung in der UB Dortmund, March 11. Conference: http://www.ub.uni-dortmund.de/Inetbib/programm.htm) Paper. Retrieved from http://www.lub.lu.se/tk/demos/DO9603-meng.html

Kraemer, R. D. (2000). Dimensões e funções do conhecimento pedagógico-musical. Em Pauta, Porto Alegre, $11(16 / 17)$.

Marcuschi, L. A. (2002, May). Gêneros textuais emergentes no contexto da tecnologia digital. In REUNIAO DO GELGRUPO DE ESTUDOS LINGUÍSTICOS DO ESTADO DE SÃO PAULO, 50, São Paulo. Gêneros textuais emergentes no contexto da tecnologia digital. São Paulo: Editora Lucerna, 23-25.

Martinoff, E. H. S. (2010). A música Evangélica na atualidade: Algumas reflexões sobre a relação entre religião, mídia e sociedade. Revista da ABEM. Londrina: ABEM, 18(23). Retrieved from http://abemeducacaomusical.com.br/revistas/revistaabem/index.php/revistaabem/article/view/217

Meneghetti, F. K. (2011). O que é um ensaio-teórico? Revista de administração contemporânea. Rio de Janeiro, RJ: ANPAD., 15(2). https://doi.org/10.1590/S1415-65552011000200010 
Montandon, M. R. (2012). Políticas públicas para formação de professores no Brasil: os programas Pibid e Prodocência. Revista da ABEM, Londrina: ABEM., 20(28). Retrieved from http://abemeducacaomusical.com.br/revistas/revistaabem/index.php/revistaabem/article/view/103

Moraes, R. (1999). Análise de conteúdo. Educação, Porto Alegre: Pontifícia Universidade Católica do Rio Grande do Sul, XXII(37), 7-31.

Oliveira, F. A. (2007). Materiais didáticos nas aulas de música do ensino fundamental: um mapeamento das concepções dos professores de música da rede municipal de ensino de Porto Alegre. Revista da ABEM. Londrina: $A B E M, 15(17)$. Retrieved from http://abemeducacaomusical.com.br/revistas/revistaabem/index.php/revistaabem/article/view/283

Penna, M. (2002). Professores de música nas escolas públicas de ensino fundamental e médio: uma ausência significativa. Revista da ABEM, Porto Alegre, 7, 7-19.

Requião, L. P. S. (2013). Educação Musical em escolas da Costa Verde, Sul Fluminense: Problematizando possibilidades de implementação da lei 11.769/2008. Revista da ABEM. Londrina: ABEM., 21(30). Retrieved from http://abemeducacaomusical.com.br/revistas/revistaabem/index.php/revistaabem/article/view/84

Vianna, F. H. M. (2016). A Trajetória da Educação Musical no Brasil e o aumento da oferta dos cursos de licenciatura no Rio Grande do Sul a partir da Lei 11.769/2008. Educação. Batatais, SP: Revista Científica do Centro Universitário Claretiano; Editors $\quad$ Note, 6(2). Retrieved from https://claretiano.edu.br/revista/90/dossie-estudos-interdisciplinares-em-educacao-musical

Website ABEM. (2018). Quem somos. Retrieved from http://abemeducacaomusical.com.br/abem.asp\#t1

Website Opus. (2018). Sobre a Opus. Retrieved from https://www.anppom.com.br/revista/index.php/opus/index

Wolffenbüttel, C. R., Riffatti, R., \& Ramos, G. da S. (2019). Mapeamento da produção científica em educação musical no Brasil - Caderno de Categorias. Montenegro: Universidade Estadual do Rio Grande do Sul. Manuscrito.

Yin, R. K. (2005). Estudo de caso: planejamento e métodos. Porto Alegre: Bookman.

\section{Notes}

Note 1. The Open University of Brazil is a Federal Government program that seeks to expand and internalize the offer of higher education courses and programs through distance education. The priority is to offer initial training to teachers in effective exercise in public basic education, but not yet graduated, and continuing education to graduates. It also intends to offer courses to leaders, managers and other professionals of basic education in public schools. Another objective of the program is to reduce inequalities in the provision of higher education and to develop a broad national system of higher education at a distance.

Note 2. The Institutional Teaching Initiation Scholarship Program (PIBID) and the Prodocence Program are actions created by the Brazilian Federal Government. The Prodocence Program aims to support projects that intend to contribute to raise the quality of undergraduate courses, with a view to valuing the training and social relevance of professionals in basic education. Pibid is an action of the National Teacher Training Policy of the Ministry of Education that aims to provide students in the first half of the undergraduate course with a practical approach to the daily life of public elementary schools and the context in which they are inserted. The program grants scholarships to undergraduate students participating in projects of initiation to teaching developed by higher education institutions in partnership with the Public Schools Network.

\section{Copyrights}

Copyright for this article is retained by the author(s), with first publication rights granted to the journal.

This is an open-access article distributed under the terms and conditions of the Creative Commons Attribution license which permits unrestricted use, distribution, and reproduction in any medium, provided the original work is properly cited. 